\title{
First evidence of the early cretaceous oceanic anoxic events (MBE and OAE1a) in the southern Tethyan margin (NE-Tunisia): biostratigraphy and shale resource system
}

\author{
Rachida Talbi ${ }^{1}$ D $\cdot$ Ahlem Amri ${ }^{1} \cdot$ Abdelhamid Boujemaa $^{1} \cdot$ Hakim Gabtni $^{1} \cdot$ Reginal Spiller $^{2} \cdot$ Raymond Levey $^{3}$
}

Received: 31 December 2020 / Accepted: 27 February 2021 / Published online: 24 March 2021

(c) The Author(s) 2021

\begin{abstract}
The Jebel Oust region (north-eastern Tunisia) recorded two levels of marine black shale in the Lower Cretaceous marly series. Geodynamic evolution, biostratigraphic and Rock-Eval analysies allow classifying those black shales as unconventional shale oil resource systems that were deposited during two oceanic anoxic events: the Middel Barremian Event "MBE" and the Early Aptian Event "OAE1a". Paleogeographic evolution highlights two transgressive-regressive cycles: the first one is Valanginian-Early Barremian, and the second is Late Barremian-Early Aptian. Each black shale deposit occurs at the end of the transgression that coincides with the highest sea level. During the Barreman-Aptian interval, sedimentation was controlled by extensional faults in a system of tilted fault blocks which were reactivated several times. Kerogen is of type I, II origin in black shales and of type III origin in marls. Tmax values indicate "oil window" stage. Average transformation ratio is around $67 \%$ and $82 \%$, respectively, in the Lower Aptian and Middel Barremian source rock related to the relatively high thermal maturity degree due to the deep burial of the later. Estimated initial hydrocarbon generation potential is moderate to high. Oil saturation index records an "oil crossover" indicating expelled and migrated hydrocarbons from the organicrich to the organic-poor facies. The petroleum system of the two mature source rocks with a high hydrocarbon generation potential enclose all elements characterizing a "shale oil hybrid system with a combination of juxtaposed organic-rich and organic-lean facies associated with open fractures".
\end{abstract}

Keywords Oceanic anoxic events $\cdot$ Shale oil system $\cdot$ Open fracture $\cdot$ Rock-Eval pyrolysis

\section{Introduction}

The Middel Barremian Event (MBE) black shales were detected in the north Tethyan margin and took place during a short episode (Coccioni et al. 1992, 2003, 2006; Sprovieri et al. 2006; Godet et al. 2006; Bodin et al. 2009; Malkoc and Mutterlose 2010; Yilmaz et al. 2012). However, the Early Aptian anoxic event ("Selli Event": "OAE1a") took place for a long time $(5 \mathrm{Ma})$ and was generally interpreted as a

Rachida Talbi

rachorg235@gmail.com

1 Georesources Laboratory, Center for Water Research and Technologies (CERTE), Technopark of Borj-Cedria, BP 273, 8020 Soliman, Tunisia

2 CEO Azimuth Energy, Bayou Island, Houston, TX, USA

3 Energy and Geoscience Institute, Wakara Way, Salt Lake City, UT, USA high-productive event well correlable, taking into account both global and local factors (Bralower et al. 1994; Leckie et al. 2002; Luciani et al. 2006; Graziano 2013; Huck et al. 2013; Moosavizadeh et al. 2014). This study presents the first recording of the oceanic anoxic event of Mid-Barremian outcrops in the southern Tethyan margin. While OAE1a, which is already well known, extended to the northern Tunisia (Talbi 1991; Elkhazri et al. 2013; Godet et al. 2014; Soua 2016; Talbi et al. 2018). A geochemical and biostratigraphic approach is used to invest organic compounds distribution through the source rocks as well as characterizating and dating the two oceanic anoxic events MBE and OAE1a recorded in the Barremian-Aptian series which outcrop in the locality of Jebel Oust (NE Tunisia) (Fig. 1). An estimate of the primary organic content, transformation ratio, retained and expelled hydrocarbons in the diverse sedimentary facies will make possible characterization of the various elements that constitute the shale oil resource system such are migration, reservoir rocks and traps. Finally, geodynamical and 


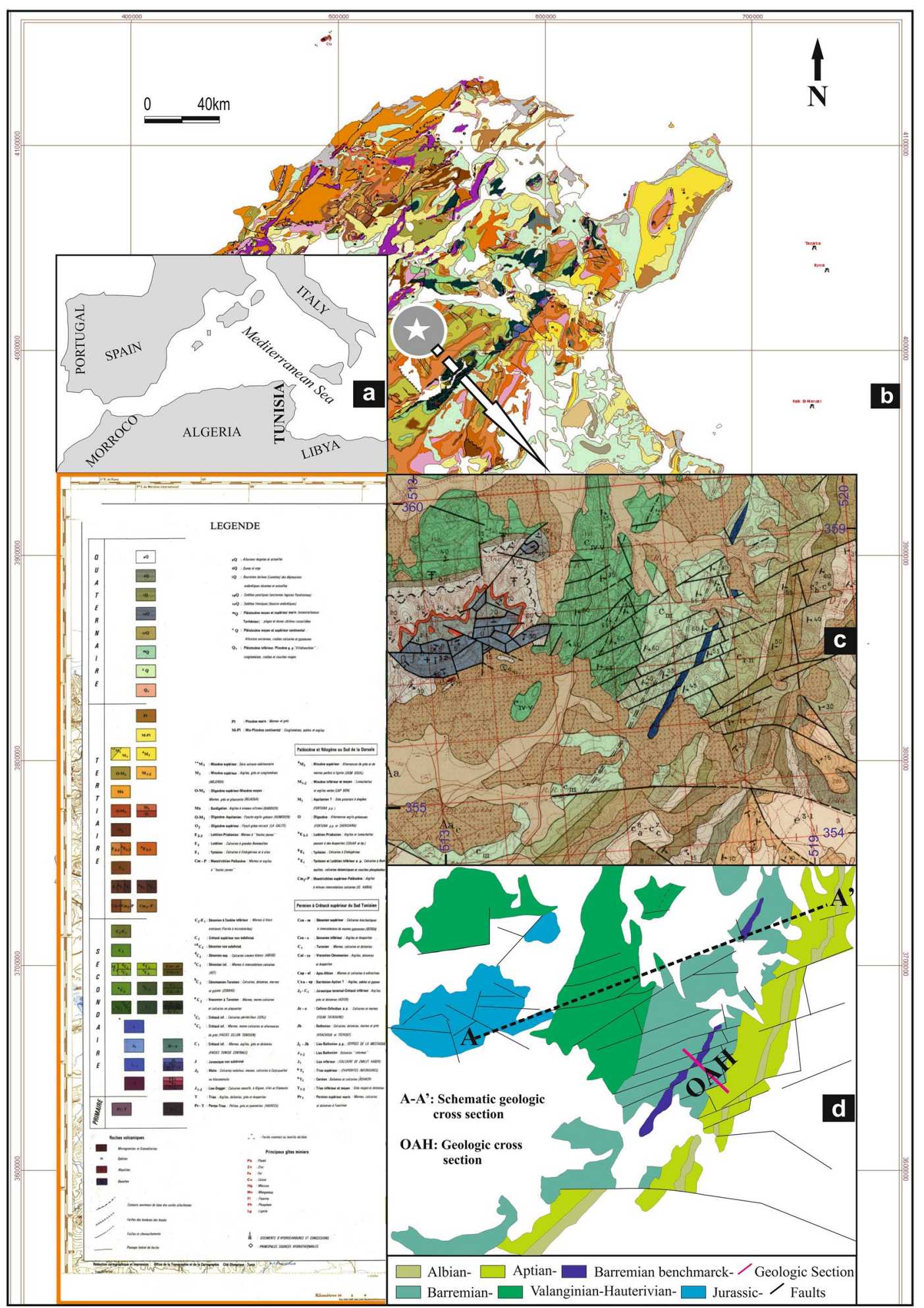

Fig. 1 a Geographic regional situation; b Northeast Tunisian geologic map, c detailed geologic map of Jebel Oust region and d simplified geologic map of study area showing OHA and AA' section location 
palaeogeographical sketch are put forward to identify the factors controlling both the deposit and the evolution of the unconventional resource system.

\section{Geological setting}

Jebel Oust region is located about thirty kilometers south of Tunis City (Fig. 1). It's a part of the Tunisian eastern Atlas, and it is represented by predominantly clayey outcrop sediment of the "Tunisian furrow". The NE-SW structure was acquired during recent compression phases (Ben Ayed 1986). The core of the anticline is represented by Jurassic neritic limestones (Sidi Khralif Formation) (Memmi 1989) that were deposited in an inner platform environment. During the Jurassic, the Jebel Oust region belonged to the stable external platform of eastern Tunisia, included in the pelagian domain (Salaj 1978). Its disconnection and total collapse at the upper Jurassic were the consequence of the sinister strike-slip faulting on Europe relative to Africa (Ben Ayed 1986). The post-Triassic sedimentary analysis shows that the maximum depth of the sedimentary basin occurred at the Valangenian-Barremian interval (M'Cherga formation). Clay-marl series deposited during this interval are about three times thicker than their equivalent of the Voconcian basin. So, the region constituted, at the early Cretaceous, the umbilicus of the eastern branch of the Tunisian furrow with about $3000 \mathrm{~m}$ thik of M'Cherga formation (Fig. 2) (Jauzein 1957; Ferjani et al. 2018).

The basin was affected at different times by rifting resulting in E-W and N-S strike-slip faults associated with tilted fault blocks. At the Lower Cretaceous, the Jebel Oust region is being pulled apart subsiding megastructure (Guiraud and Maurin 1991). It was an example of extensional down faulted depression in the Tunisian furrow during the JurassicTerminal Barremian interval. The Barremo-Aptian period was characterized by a distensive NE-SW tectonic episode (Castany 1954; Chihi et al. 1984; Saïd et al. 2011; Gharbi et al. 2015) which affects the depth and the inner architecture (Fig. 3).

During Aptian-Albian interval (Fahdene formation), the Tunisian furrow was marked by distensive tectonic activity reactivated old deep faults and created halokinetic activities that contributed to Triassic salt dome genesis at the core of the current anticline structures (Smati 1986; Perthuisot et al. 1988) (Fig. 3). This produced inequalities, anisopaque sedimentation, unconformities, dismantling breaches and reef constructions (Burollet 1991; Perthuisot et al. 1988). The geological cross-section of the study area: OAH (Oust Ain Hamam) is located in the Jebel Oust area Its GPS coordinates are N 36030 '59.3; E 010005 '38.9. This geologic section crosses a clay limestone series of Barremian-Aptian age, with about 900-m-thickness (Fig. 1d).

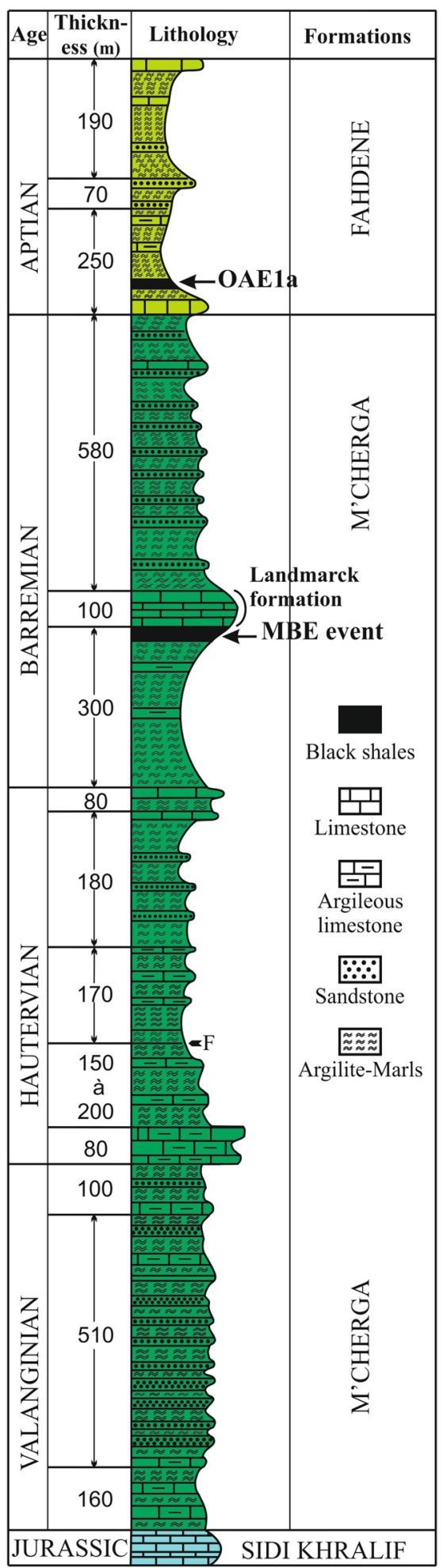

Fig. 2 General log showing main geologic formations outcropping in Jebel Oust region (modified, from Memmi 1989) 


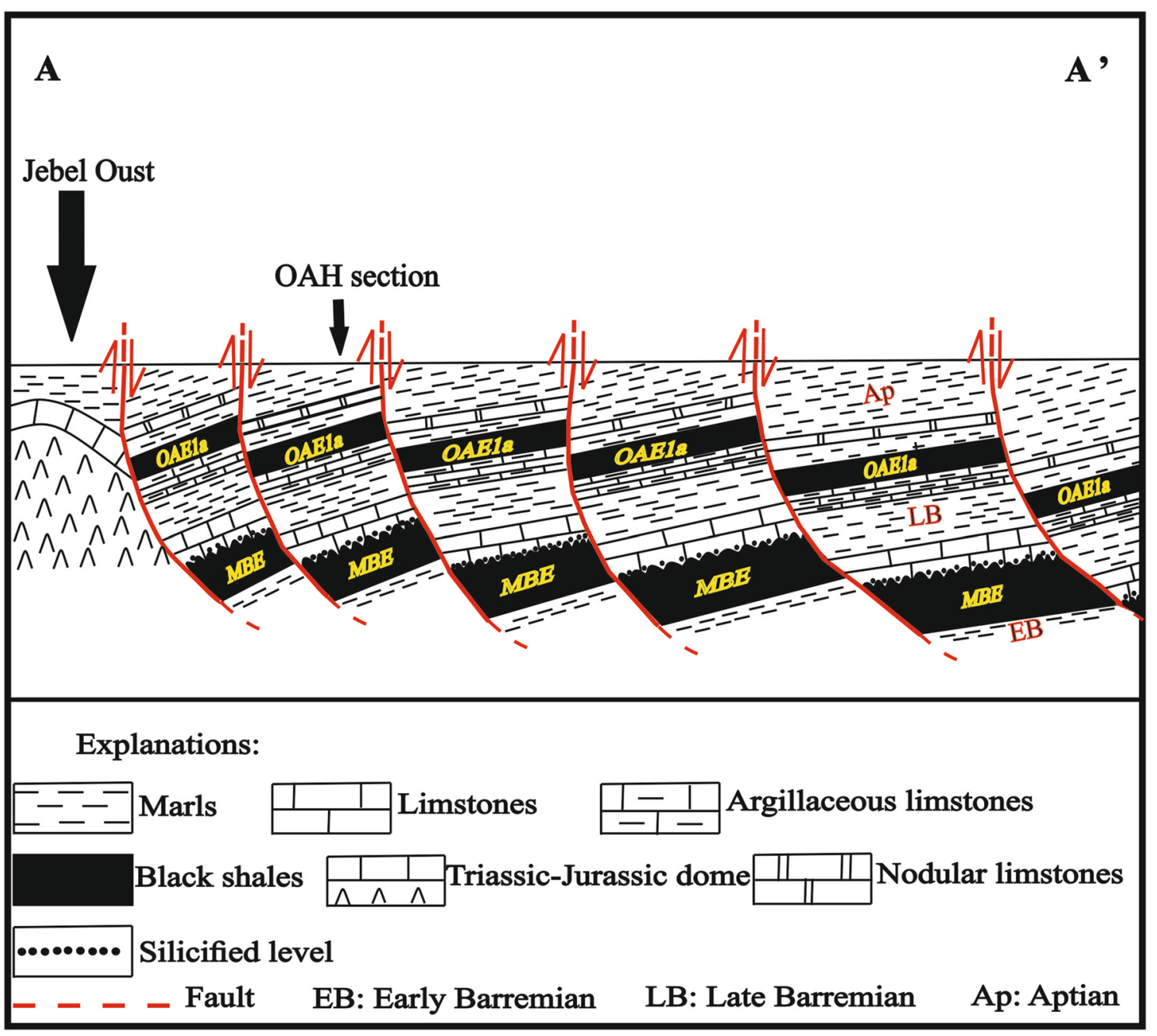

Fig. 3 Schematic NW-SE cross-section showing black shales related to MBE and OAE1a within tilted blocks, guiding the Jebel Oust Barremian-Aptian source rock sedimentation

\section{Paleogeographic setting}

The depositional environment during the Barremian-Aptian interval has been controlled by the structure of the seafloor that has affected types, distribution and thickness of sedimentary facies (Jauzein 1957; Fournie et Pacaud 1973; M'rabet 1981; Memmi 1989) (Fig. 4).

Two sedimentary mega-sequences were deposited during the Lower Cretaceous transgressive-regressive cycles (Memmi 1989). The first mega-sequence was regressive during Tithonic-Early Barremian interval. It filled the collapsed areas by predominate clay-fine quartz deposits that has been carried by southern turbidity currents. Those arrived from central Tunisia which was occupied by a prograding deltaic complex. The second mega-sequence which is transgressive-regressive with bathyal deep sea sedimentation started at Middle Barremian and ended in Gargasian (Fig. 2). This sequence is formed by argillite with fine sandstone pasts and clay-carbonates (Jauzein 1957; Burollet et al. 1983; Memmi 1989). In the southern domain of Tunisian furrow, the Kairouan Island remained emerged during the entire Early Cretaceous interval, and the North-South Axis was less subsiding and recognized condensed levels (Jauzein 1967; Marie et al. 1982, Burollet et al. 1983; Memmi 1989) (Fig. 4).

\section{Materials and methods}

After geological survey of the Early Cretaceous outcropping strata in Jebel Oust region, a geological cross-section $(\mathrm{OAH})$ was constructed through the Barremian-Aptian series (Figs. 2 and 5). A systematic sampling is carried out in order to study both the released microfauna and the organic geochemistry analysis. The sampling becomes very tight near the Barremian-Aptian limit (Fig. 5). To 
Fig. 4 Palaeogeographic map of Tunisia in the lower cretaceous (Marie et al. 1982)

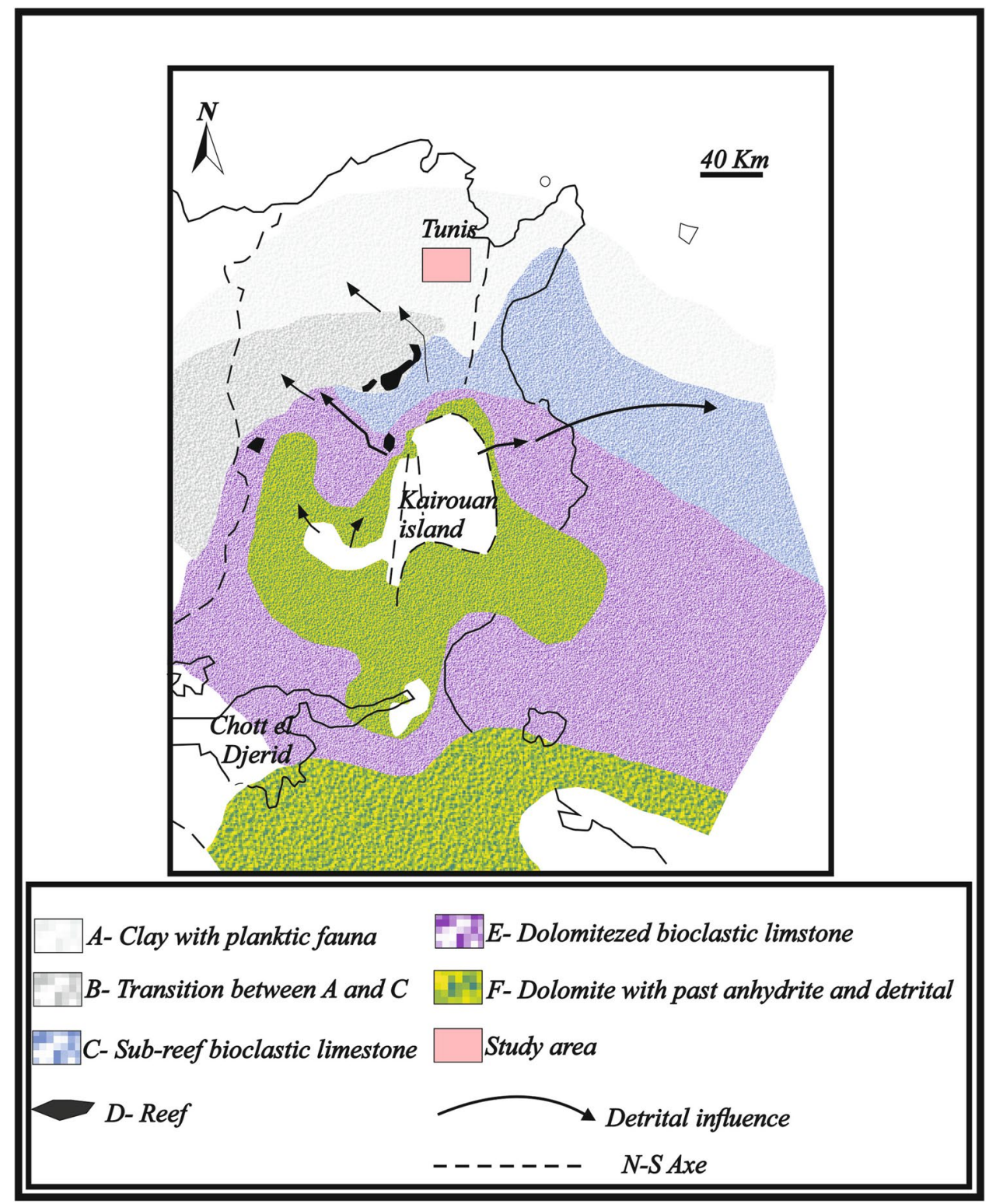

study the released microfauna, we used the standard technique of washing the marls. Planktic, benthic foraminifers and Ostracods are observed with a Scanning Electron Microscope. The biostratigraphic approach is based on the contribution of these species which are of great interest in dating the Barremian-Aptian series. The petroleum shale resource system evaluation of the Barrem-Aptian series was realized based on organic geochemistry analysies that were conducted on 15 rock samples using Rock-Eval 6 programmed pyrolysis. This technical method (Espitalié et al. 1977; Sykes and Snowdon 2002) measures the total organic carbon (TOC), and the compounds released during organic matter pyrolysis of $100 \mathrm{mg}$ of finely ground sediment under an inert atmosphere (Helium) and by programming the heating temperature from $180-850{ }^{\circ} \mathrm{C}$ at a rate of $25^{\circ} \mathrm{C} / \mathrm{mn}$. A pyrogram showing three peaks related to three organic compounds is provided: the S1 and S2 peaks correspond, respectively, to the free hydrocarbon quantities released at $180{ }^{\circ} \mathrm{C}$ and to the potential hydrocarbons obtained by thermal cracking of the insoluble organic matter (kerogen) at a temperature ranging between 180 and $550{ }^{\circ} \mathrm{C}$. The $\mathrm{S} 3$ peak represents the oxygen compounds in organic matter, and the maximum temperature (Tmax) measured at the summit of the $\mathrm{S} 2$ peak corresponds to the kerogen thermal maturity degree. Finally, the highest temperature (up to $550{ }^{\circ} \mathrm{C}$ ) led to determine TOC content. Several parameters are calculated using $\mathrm{S} 1, \mathrm{~S} 2$ and $\mathrm{S} 3$ such as hydrogen index $(\mathrm{HI}=(\mathrm{S} 2 \times 100) / \mathrm{TOC}$ in $\mathrm{mg} \mathrm{HC} / \mathrm{g}$ TOC $)$, oxygen index $(\mathrm{OI}=(\mathrm{S} 2 \times 100) / \mathrm{TOC}$ in $\mathrm{mg} \mathrm{CO} 2 / \mathrm{g}$ TOC $)$ and $\mathrm{S} 2 / \mathrm{S} 3$ ratio. All these parameters are classical and are 


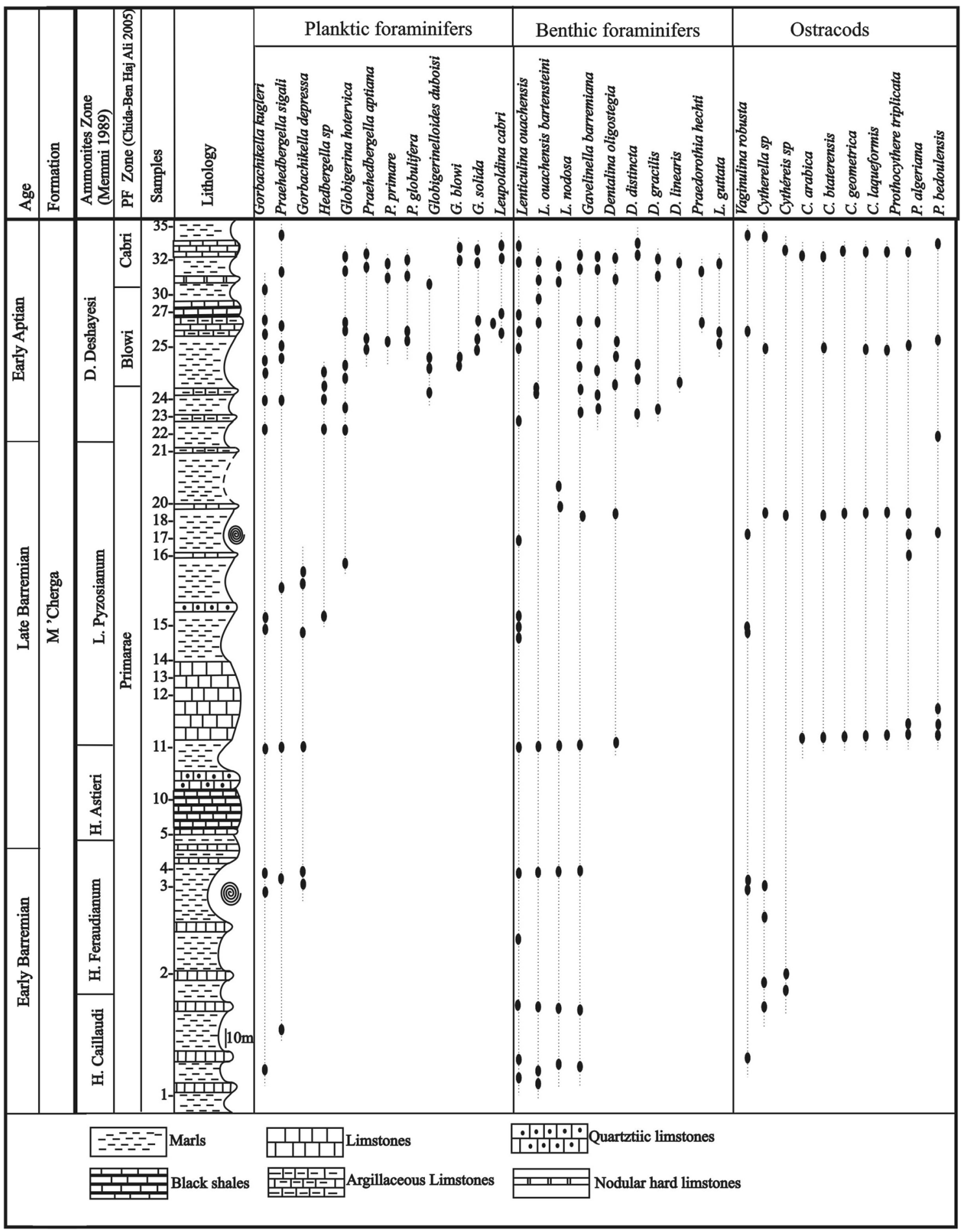

Fig. 5 Detailed geologic section showing vertical distributions of microfauna specimens in Jebel Oust Barremian-Aptian series (OAH section)

used for petroleum source rock characterization. Parameters used as indicators for production and oil expulsion have been invented, and others have changed indication such as retained hydrocarbons $(\mathrm{RHC}=\mathrm{S} 1+\mathrm{S} 2)$, hydrocarbon generation potential $(\mathrm{HGP}=\mathrm{S} 2)$, Oil saturated index
$(\mathrm{OSI}=(100 \times \mathrm{S} 1) / \mathrm{TOC})$. Original organic parameters are estimated ( $\mathrm{TOC}_{0}$ and $\mathrm{S} 2_{0}$ ) according to Jarvie et al. (2007) method $\left(\mathrm{TR}=\left(\mathrm{HI}_{0}-\mathrm{HI}\right) / \mathrm{HI}_{0}\right)$. 


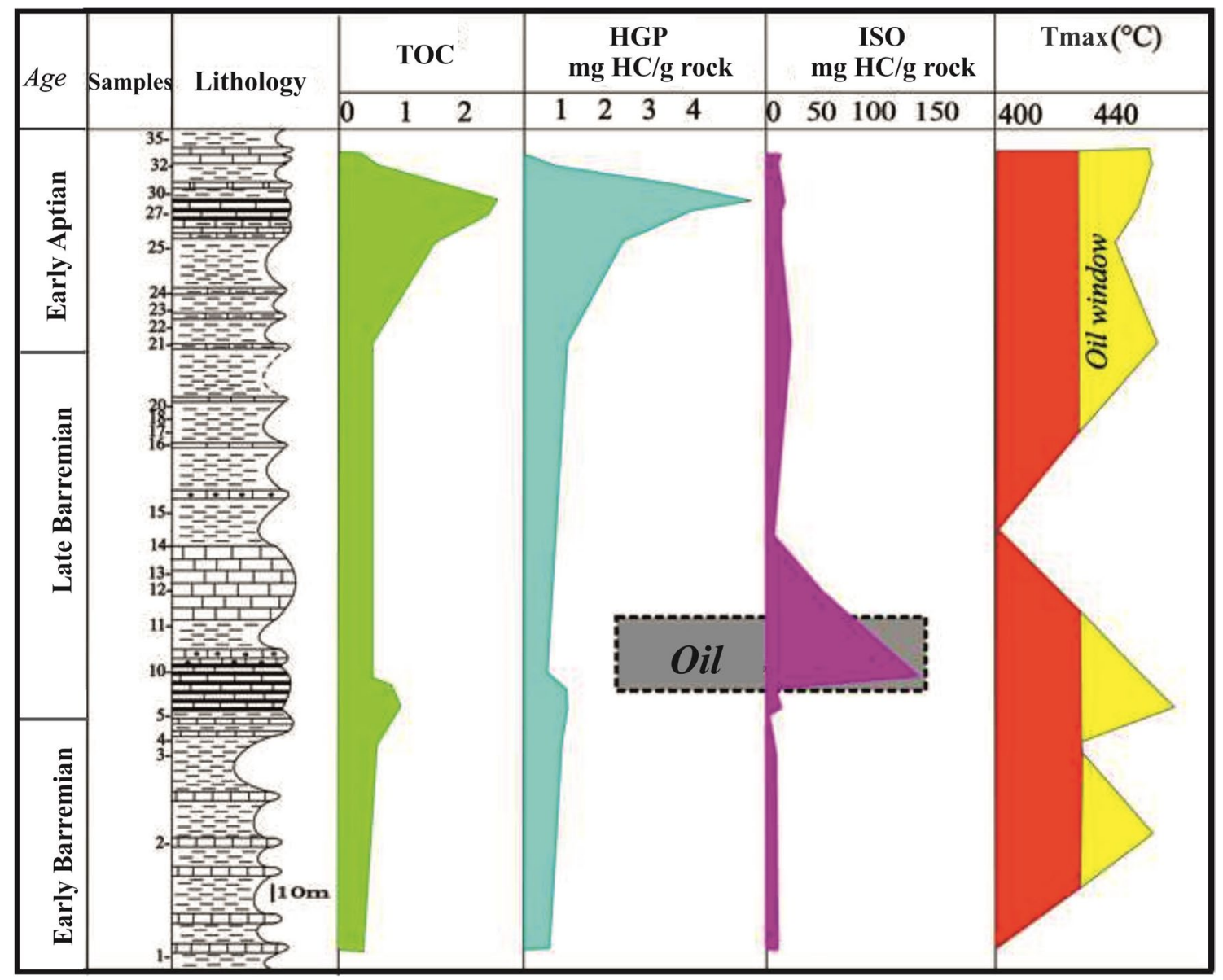

Fig. 6 Variations of TOC, Hydrocarbon generation potential (HGP), Oil saturation index (OSI) and Tmax showing "oil crossover" in Jebel Oust Barremian-Aptian series

\section{Results}

\section{Biostratigraphy study of the Barremian-Aptian interval}

Biostratigraphy of the geological cross-section (Fig. 4) refers to microfaunal assemblage of planktic and benthic foraminifers and age determinations are cross-checked with the documented Ammonite zonation for the Barremian-Aptian stages carried out by Memmi (1989). The bottom of the section begins with gray marls that are surmounted by alternations of consolidated marls, limestones and clayey limestones with gray marls intercalation which contain the following planktic foraminifera: Gorbachikella kugleri and Praehedbergella sigali and benthic foraminifera: Lenticulina ouachensis ouachensis, L. ouachensis bartensteini L. nodosa, L. eichenbergi, Gavelinella barremiana, Dentalina oligostegia, Praedorothia hechti, Epistomina $s p$ with rare ostracods, radiolarian and echinoderms. This series belongs to the Holcodiscus caillaudi ammonite zone that marks the Early Barremian.
On this series, are deposited clayey limestones including six black shale levels. The last two levels are silicified, ending by an eroded surface which could affect the high submarine forms (horsts). This may be induced by tectonic instability occurring during a short time at the end of the Early Barremian. Following this eroded surface, a hard nodular pure limestone bar was settled with about $100 \mathrm{~m}$ thickness that serve as a regional landmark formation. Those limestones show slumps on curved slip surfaces and did not provide characteristic fauna. They were attributed to the Early Late Barremian (Memmi 1989).

A thick greenish marly series $(200 \mathrm{~m})$ with thin quartz beds ends the Barremian. These series contain the following faunal association: Gorbachikella depressa, Gorbachikella kugleri, Praehedbergella sigali, Hedbergella sp, Globigerina hotervica, Lenticulina ouachensis ouachensis, L. ouachensis bartensteini L. nodosa, L. eichenbergi, Gavelinella barrigia, Dentalina olivia, D. D. gracilis with some ostracods: Cytherella sp, Cythéreis sp and C. arabica. This microfauna association and the ammonite Leptoceras puzosianum mark the Late Barremian (Salaj 1980; 
Memmi 1989; Bellier and Moullade 2002; Chida-Ben Haj Ali 2005).

The early Aptian is represented at its bottom by grayblack marls interspersed by clay limestones which support brown marls, surmounted by two levels of black shale and dark clayey limestones. This series provides the following planktic fauna association: Gorbachikella kugleri, Praehedbergella sigali, Praehedbergella aptiana with a benthic fauna composed of Lenticulina ouachensis, L. ouachensis bartensteini, L. nodosa, L. eichenbergi, Gavelinella barremiana, Dentalina oligosteagia, D. distinct. gracilis and Epistomina sp.

The top of this series is mainly argillaceous and delivered a marine microfaunal association composed with: Praehedbergella sigali, P. primare, P. aptiana, P. globulifera, Globigerinelloides duboisi, G. blowi, G. solida, Leupoldina cabri, with benthic fauna: Praedorothia hechti, Lenticulina ouachensis, L. nodosa, L. guttata, Gavelinella barremiana, Ammodiscus sp and Vaginulina robusta with ostracods: cyhthereis sp, C. arabica, C. btaterensis, C. geometrica, C. laqueformis, Prothocythere triplicata, P. algeriana and $P$. bedoulensis, and the ammonite Deshayesites deshayesi marking the Late Bedoulian (Fig. 5).

The biostratigraphic study of the Jebel Oust Barremian-Aptian series allows identifying two sets of black shale. The first one occurred at Early Late Barremian (Fig. 5), and is framed by two biohorizons: $P$ sigali and $G$ kugleri at the base and $H$ caillaudi at the top. It settled at the end of the Early Barremian just before the deposition of the regional landmark formation, with the hard nodular pure limestones that is attributed to the Late Barremian (Figs. 2 and 5). We date this event in Jebel Oust "Early Late Barremian" but we must adopt the same designation "MBE: Middle Barremian Event" establish for the northern Tethyan margin event (Coccioni et al. 1992, 2003, 2006; Sprovieri et al. 2006; Bodin et al. 2009; Malkoc and Mutterlose 2010;

Table 1 Organic geochemical data from Rock-Eval pyrolysis: total organic carbon (TOC), hydrogen index (HI), oxygen index (OI) and anoxic index (HI/OI) of Jebel Oust Barremian series

\begin{tabular}{llllll}
\hline Age & Sample & TOC $(\%)$ & HI $(\mathrm{mg} / \mathrm{g})$ & OI $(\mathrm{mg} / \mathrm{g})$ & HI/OI \\
\hline Barremian & OAH14 & 0.54 & 115 & 339 & 0.33 \\
& OAH12 & 0.06 & 433 & 17 & - \\
& OAH10 & 0.16 & 769 & 425 & 1.81 \\
& OAH09 & 0.49 & 82 & 112 & 0.74 \\
OAH07 & 0.82 & 87 & 71 & 1.22 \\
OAH05 & 0.93 & 86 & 85 & 1.01 \\
OAH03 & 0.60 & 110 & 282 & 0.39 \\
OAH02 & 0.47 & 123 & 149 & 0.83 \\
OAH01 & 0.33 & 112 & 406 & 0.28 \\
& Average & 0.49 & 213 & 209 & 0.82 \\
\hline
\end{tabular}

Yilmaz et al. 2012). That's why this first set of black shale is considered to have a Middle Barremian age that had been formed when a short anoxic/dyoxic event occurred. It is the first recorded evidence of Mid-Barremian Event (MBE) in the Southern Tethyan margin that is widely represented along the Northern margin (Coccioni et al. 2003; Yilmaz et al. 2012; Wulf et al. 2020). The second set of black shale is dated lyEar Aptian (Figs. 2 and 5) and was settled between two biohorizons. The basal one is marked by G.blowi and Deshayesites deshayesi biozones, and the upper one is formed by L. cabri. This event is taken in the "Selli Event" OAE1a widely extended to the Tunisian furrow domain (Talbi 1991; Soua 2016; Talbi et al. 2018) as well as to the north Tethyan margin (Bralower et al. 1994; Leckie et al. 2002; Luciani et al. 2006; Graziano 2013; Moosavizadeh et al. 2014).

\section{Distribution of organic matter in various sedimentary facies}

The use of the basic Rock-Eval pyrolysis parameters is to identify the petroleum source rock potential. The results of rock samples pyrolysis of Barremian-Aptian series are given in Tables $1,2,3,4,5$, and 6 . They indicate low to high TOC contents ranging from 0.06 and $0.93 \%$ weight in the Barremian series with an average of about $0.5 \%$ weight (Table 1). Those of the Early Aptian facies record TOC values ranging from 0.27 to $2.49 \%$ with an average of $1.28 \%$ weight (Table 2).

Table 2 Organic geochemical data from Rock-Eval pyrolysis: total organic carbon (TOC), hydrogen index (HI), oxygen index (OI) and anoxic index (HI/OI) of Jebel Oust Aptian series

\begin{tabular}{llllll}
\hline Age & Sample & TOC $(\%)$ & HI $(\mathrm{mg} / \mathrm{g})$ & OI $(\mathrm{mg} / \mathrm{g})$ & HI/OI \\
\hline Aptian & OAH34 & 0.27 & 96 & 200 & 0.48 \\
& OAH33 & 0.47 & 115 & 143 & 0.80 \\
& OAH29 & 2.49 & 174 & 45 & 3.86 \\
& OAH28 & 2.38 & 135 & 63 & 2.14 \\
& OAH25 & 1.53 & 132 & 142 & 0.93 \\
& OAH22 & 0.57 & 128 & 98 & 1.30 \\
& Average & 1.28 & 130 & 115 & 1.13 \\
\hline
\end{tabular}

Table 3 Average organic geochemical data recorded in the various sedimentary facies of Jebel Oust Barremian-Aptian series

\begin{tabular}{lllll}
\hline Sedimentary facies & TOC $(\%)$ & HI $(\mathrm{mg} / \mathrm{g})$ & OI $(\mathrm{mg} / \mathrm{g})$ & HI/OI \\
\hline Black shales & 1.66 & 120 & 66 & 2 \\
Marls & 0.76 & 117 & 292 & 0.4 \\
Limestones and & 0.35 & 302 & 195 & 1.5 \\
$\quad \begin{array}{l}\text { silicified black } \\
\text { shales }\end{array}$ & & & & \\
\hline
\end{tabular}


Table 4 Average organic geochemical data from Rock Eval analyses recorded in MBE and OAH1a organic-rich black shales of Jebel Oust

\begin{tabular}{llllllllll}
\hline Anoxic event & Sample & TOC $(\%)$ & Tmax $\left({ }^{\circ} \mathrm{C}\right)$ & $\mathrm{TOC}_{0}(\%)$ & $\mathrm{S}_{0}(\mathrm{mg})$ & $\mathrm{TR}(\%)$ & $\mathrm{RHC}(\mathrm{mg} / \mathrm{g})$ & $\mathrm{RHC}(\%)$ & $\mathrm{EHC}(\%)$ \\
\hline OAE1a & OAH29 & 2.49 & 447 & 4.35 & 19.88 & 63 & 4.78 & 24 & 76 \\
& OAH28 & 2.38 & 448 & 4.12 & 18.83 & 72 & 3.55 & 19 & 81 \\
\multirow{3}{*}{ MBE } & Average & 2.43 & 447 & 4.23 & 19.35 & 67 & 4.16 & 21 & 78 \\
& OAH07 & 0.82 & 453 & 1.43 & 6.53 & 82 & 0.84 & 13 & 87 \\
& OAH05 & 0.93 & 455 & 1.62 & 7.4 & 82 & 0.85 & 18 \\
& Average & 0.87 & 454 & 1.52 & 6.96 & 82 & 0.84 & 15 & 84 \\
\hline
\end{tabular}

Table 5 Contents of present day and initial total organic carbon (TOC, $\left.\mathrm{COT}_{0}\right)$, initial hydrocarbon generation potential $\left(\mathrm{S}_{0}\right)$, transformation rate (TR), retained hydrocarbons (RHC), expelled hydro- carbons (EHC), hydrocarbon generation potential, oil saturation index (OSI) and $\mathrm{T}_{\max }$ in the Jebel Oust Barremian series

\begin{tabular}{|c|c|c|c|c|c|c|c|c|c|c|c|}
\hline Age & Sample & TOC $(\%)$ & $\mathrm{TOC}_{0}(\%)$ & $\mathrm{S} 2_{0}(\mathrm{mg} / \mathrm{g})$ & TR $(\%)$ & RHC (mg/g) & RHC (\%) & $\mathrm{EHC}(\%)$ & $\operatorname{HGP}(\mathrm{mg} / \mathrm{g})$ & OSI & $\operatorname{Tmax}\left({ }^{\circ} \mathrm{C}\right)$ \\
\hline \multirow[t]{10}{*}{ Barremian } & OAH14 & 0.54 & 0.75 & 1.60 & 54 & 0.67 & 42 & 58 & 0.62 & 9 & - \\
\hline & OAH12 & 0.06 & 0.09 & 0.57 & - & 0.29 & 51 & 49 & 0.26 & 50 & 428 \\
\hline & OAH10 & 0.16 & 0.25 & 1.59 & - & 1.45 & 91 & 9 & 1.23 & 137 & 460 \\
\hline & OAH09 & 0.49 & 0.68 & 1.45 & 67 & 0.45 & 31 & 69 & 0.40 & 10 & 445 \\
\hline & OAH07 & 0.82 & 1.43 & 6.53 & 82 & 0.84 & 13 & 87 & 0.71 & 16 & 453 \\
\hline & OAH05 & 0.93 & 1.62 & 7.4 & 82 & 0.85 & 18 & 82 & 0.80 & 5 & 455 \\
\hline & OAH03 & 0.6 & 0.84 & 2 & 56 & 0.72 & 36 & 64 & 0.66 & 10 & 422 \\
\hline & OAH02 & 0.47 & 0.74 & 4.70 & 66 & 0.63 & 13 & 87 & 0.58 & 11 & 449 \\
\hline & OAH01 & 0.33 & 0.46 & 0.98 & 55 & 0.41 & 42 & 58 & 0.37 & 12 & - \\
\hline & Average & 0.49 & 0.76 & 2.98 & 66 & 0.70 & 37 & 62 & 0.62 & 29 & 444 \\
\hline
\end{tabular}

Table 6 Contents of present day and initial total organic carbon (TOC, $\mathrm{COT}_{0}$ ), initial hydrocarbon generation potential $\left(\mathrm{S}_{0}\right)$, transformation rate (TR), retained hydrocarbons (RHC), expelled hydro- carbons (EHC), hydrocarbon generation potential, oil saturation index (OSI) and $\mathrm{T}_{\max }$ in the Jebel Oust Aptian series

\begin{tabular}{|c|c|c|c|c|c|c|c|c|c|c|c|}
\hline Age & Sample & TOC (\%) & $\mathrm{TOC}_{0}(\%)$ & $\mathrm{S} 2_{0}(\mathrm{mg} / \mathrm{g})$ & TR $(\%)$ & RHC (mg/g) & RHC (\%) & $\mathrm{EHC}(\%)$ & HGP & OSI & $\operatorname{Tmax}\left({ }^{\circ} \mathrm{C}\right)$ \\
\hline \multirow[t]{7}{*}{ Aptian } & OAH34 & 0.27 & 0.43 & 2.70 & 73 & 0.30 & 11 & 89 & 0.26 & 15 & 447 \\
\hline & OAH33 & 0.47 & 0.74 & 4,70 & 68 & 0.59 & 13 & 87 & 0.54 & 11 & 448 \\
\hline & OAH29 & 2.49 & 4.35 & 19.88 & 63 & 4.78 & 24 & 76 & 4.33 & 18 & 446 \\
\hline & OAH 28 & 2.38 & 4.12 & 18.83 & 72 & 3.55 & 19 & 81 & 3.21 & 14 & 444 \\
\hline & OAH 25 & 1.53 & 2.1 & 3.80 & 47 & 2.09 & 55 & 45 & 2.02 & 05 & 439 \\
\hline & OAH22 & 0.57 & 0.79 & 1.69 & 49 & 0.86 & 51 & 49 & 0.73 & 23 & 451 \\
\hline & Average & 1.28 & 2.09 & 8.60 & 62 & 2.03 & 29 & 71 & 1.84 & 14 & 446 \\
\hline
\end{tabular}

Analysis of TOC content according to the lithological variations shows that black shales record the highest content with a mean value of $1.66 \%$. The marls contain moderates TOC values middling $0.76 \%$. While the average TOC content in limestones and silicified black shales are low, not exceeding $0.35 \%$ (Table 3 ).

The evaluation of the quality of the organic matter using the hydrogen (HI) and the oxygen index (OI) as quality and origin kerogen indicators shows (Table 3), first that the HI average values are moderate and similar in black shales and marls (respectively equal to 120 and $117 \mathrm{mg} \mathrm{HC} / \mathrm{g}$
TOC) but higher in silicified black shales and limestones (302 mg HC/g TOC). Average OI values are low in black shales (66 mg CO2/g TOC), higher in marls (295 mg CO $2 / \mathrm{g}$ TOC) and medium in silicified black shales and limestones (195 mg CO2/g TOC). These variations indicate that the organic-rich black shales record the best quality of the kerogen because they are with low oxygen compounds representing a very well preservation degree in an anoxic/dyoxic deposited environment. However, kerogen of marls is rich oxygen compounds deriving probably from continental origin (Petersen et al. 2008). Whereas organic-poor facies that 


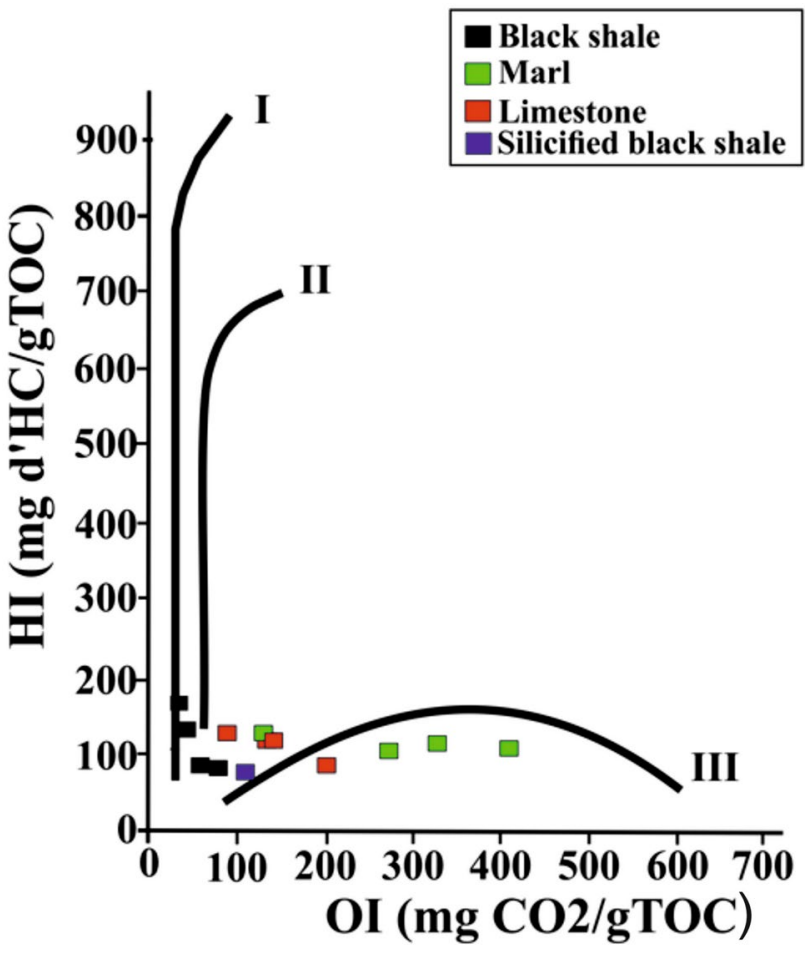

Fig. 7 Diagram HI/OI showing type I (alga/sapropelic), type II (phytoplanktonic) and type III (lignocellulosic) kerogen in the different sedimentary facies from Jebel Oust Barremian-Aptian series

are represented by silicified black shales, and limestones are similar to hydrocarbons that may have migrated from organic-rich facies (organic-rich black shales and organicrich marl). This is demonstrated by OSI (oil saturation index) values which recorded a high values, greater than 100\% (Jarvie 2012) (Fig. 6).

The HI/OI diagram (Fig. 7) can display and compare the origin and quality of organic compounds of the different sedimentary facies. This diagram, established by Espitalié et al. (1977) shows the three lines of the nature and origin of kerogen: type I, type II and type III. These three lines differ in the values of $\mathrm{HI}$ and OI. Type I kerogen is characterized by a high initial HI and a low initial OI. This kerogen is derived from organic algal / sapropelic material. Type II kerogen is characterized by intermediate HI and OI values which originate mainly from marine organic matter deposited in reducing sedimentary environments. Finally, type III kerogen has a low initial HI and OI and is of terrestrial plant origin. It shows that black shale organic matter kerogen is marine plankton: type I, II. While marls contain allochthonous organic matter of lignocellulosic origin: type III. Limestone and silicified black shales samples are with intermediate organic matter quality (Fig. 7).

All these results demonstrate that organic-rich black shales can be considered as the real source rock facies as well as the organic-rich marls. The organic-poor limestones and silicified black shales can be considered as thin reservoirs intercalated within the shale resource. HI/OI index that is equal to S2/S3 index (Calvert et al. 1992) characterize the anoxic degree. It is higher in organic-rich black shales (average $\mathrm{HI} / \mathrm{OI}=2$ ) than in organic-rich marls (average $\mathrm{HI} / \mathrm{OI}=1.5$ ). Black shales are then the most representative facies of anoxic events. They can be considered as the indicators facies of these events which contain the highest organic matter contents that are preserved under dyoxic/anoxic conditions. Through their millimeter laminations, they would have recorded the seasonal variations, the extreme seafloor stability and the hydrodynamic lowenergy provided by water-mass stratification (Demaison and Moore 1980).

\section{Characterization of the two oceanic anoxic events MBE and OAE1a}

MBE anoxic event that marks the Early Barremian (Figs. 2 and 5) is represented by six layers laminated black shales alternating with thin dark-clay limestones and marls (Fig. 8). These black shales recorded a high TOC content with an average closing to $0.9 \%$ rock (Table 3 ). The second event OAE1a dated Early Aptian (Figs. 2 and 5) is represented by two layers of black shale enclosed in dark-gray marls. It recorded the highest TOC values with an average nearby $2.5 \%$ (Table 4) (Fig. 8). Hydrogen index values are moderate prone hydrocarbons in the two anoxic events ( $<300 \mathrm{mg} / \mathrm{g}$ TOC) caused by the relatively high maturity degree (oil window) and hydrocarbons generation and expelledation that is demonstrated below.

The HI/OI ratio which is equal to the S2/S3 indicates the degree of anoxia of the deposition environment (Calvert et al. 1992, Talbi et al.2018). The highest values of this ratio are recorded in the Early Aptian (HI/OI $>3$ ) (Table 2), while Barremian interval is marked by a moderate HI/OI ratio $(1<\mathrm{HI} / \mathrm{OI}>2)$ (Table 1$)$. Figure 8 shows multiple peaks in HI/OI curve but two peaks are appropriating to anoxic conditions because they are related to the high organic matter contents (the other small peaks are not significant because of their low TOC contents). These two peaks related to the high anoxic degree correspond to the two Barrimian-Aptian anoxic events. The highest peak gives the undisputed supremacy of OAE1a anoxic crisis compared to MBE one (Fig. 8). We consider that the dyoxic/anoxic conditions that were developed at the Early Aptian would have been initiated at the Early Late Barremian event and had reached the highest level when the OAE1a occured. This may be related to the several modifications in biotic and abiotic factors that could have caused 


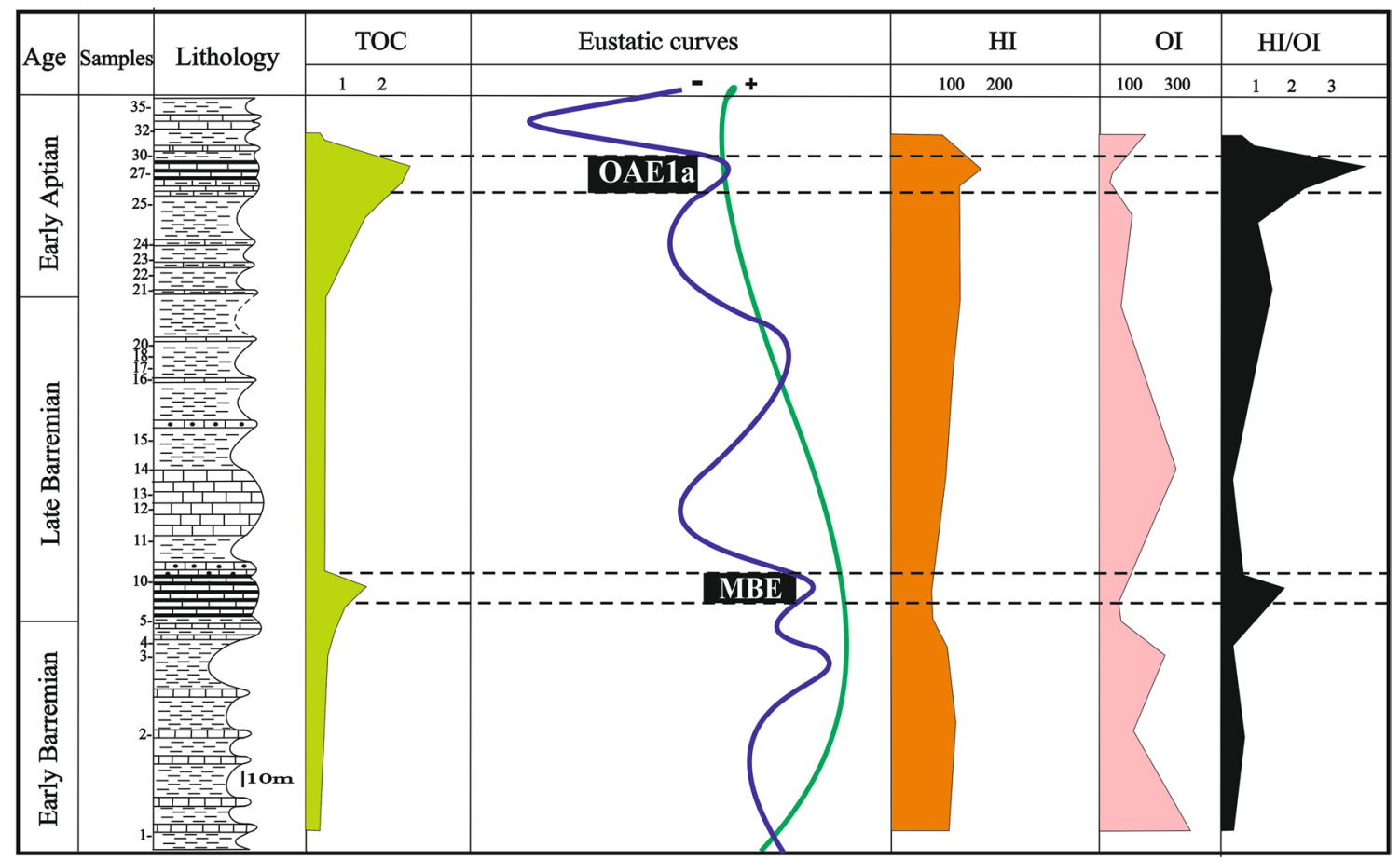

Fig. $8 \mathrm{MBE}$ and OAE1 oceanic anoxic events correlation with the organic geochemical parameters (TOC, HI, OI and HI/OI) of Jebel Oust Barremian-Aptian source rocks compared to their Western
North Atlantic equivalents (Leckie et al. 2002) and the Vail sea level curve (Vail et al. 1977)

to determine the transformation ratio (TR), the initial total organic carbon $\left(\mathrm{COT}_{0}\right)$ and the initial hydrocarbon generation potential $\left(\mathrm{S}_{0}\right)$ knowing the initial hydrogen index $\left(\mathrm{IH}_{0}\right)$ (Jarvie et al. 2007). The transformation ratio (TR) represents the percentage of kerogen having undergone thermal cracking between the initial state (state of immature organic matter) and the current state (present day measures):

\section{$\mathrm{TR}=\mathrm{HI}_{0} \mathrm{HI} / \mathrm{HI}_{0}$.}

To apply this method for evaluating hydrocarbon generative capacities, $\mathrm{IH}_{0}$ is estimated at 475 for black shales with type I, II organic matter, and at 250 for marls with type III organic matter. For organic-poor facies (limestones and silicified black shales), we use the mean of the two values (Jarvie et al. 2007). The estimated values of $\mathrm{TOC}_{0}, \mathrm{~S}_{0}$ and TR are given in Tables 4, 5, and 6 and Fig. 9. TR is about $50 \%$ in the marl organic matter, and ranges from 60 to $80 \%$ in black shales. This difference reflects the diversity in organic matter origin in these two types of facies, which is type I, II in black shales and type III in marls. In fact, type III organic matter is more riches in aromatic compounds and provides more energy to crack its hydrocarbons. The initial hydrocarbons generation potential $\left(\mathrm{S} 2_{0}\right)$ are exceptionally higher in black shales particularly those recorded in OAE1a than in the other sedimentary facies. They range from 18.83 to $19.88 \mathrm{mg} \mathrm{HC} / \mathrm{g}$ TOC and from 6.53 to $7.40 \mathrm{mg} \mathrm{HC} / \mathrm{g}$ TOC, respectively, in OAE1a and MBE organic-rich black a method has been defined by Jarvie et al. (2007) that allows
Rock Eval parameters as common geochemical measurements such as total organic carbon (TOC), hydrocarbon generation potential (S2) and free hydrocarbons (S1) are present day values. These measurements are carried on rocks whose organic material have undergone a less or high thermal maturity degree and therefore lacked a part of their organic compounds (hydrocarbons) by migration. The initial state in which the organic matter was immature that can be estimated by calculating the initial organic parameters. So, 


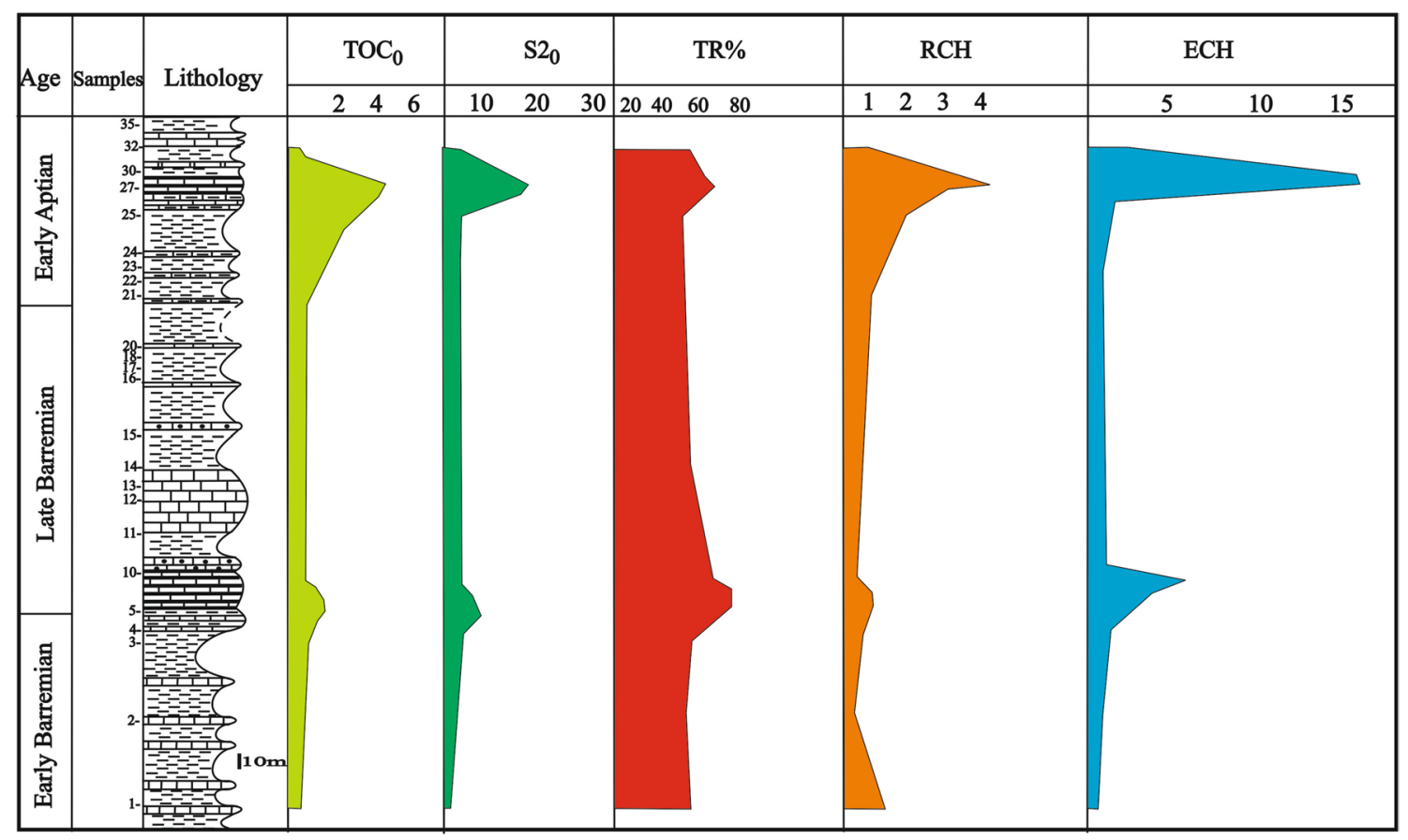

Fig. 9 Variations of initial $\mathrm{OM}$ contents $\left(\mathrm{TOC}_{0}, \mathrm{~S} 2_{0}\right)$ transformation ration (TR), retained and expelled hydrocarbons (RHC, EHC) of Jebel Oust Barremian-Aptian series

shales. In marls, $\mathrm{S} 2_{0}$ is with relatively lower to moderate values (0.98-3.8 mg/g) (Table 4) (Fig. 9). This could be explained by a greater degree of preservation and/or organic productivity in the depositional environment of the black shales than in those of marls. However, organic-poor limestones and silicified black shales have recorded the lowest values of $\mathrm{TOC}_{0}, \mathrm{~S}_{2}$ and TR. Those sedimentary facies represented a short oxic phase or resedimented deposits that may be moved throw sliding down slops.

It should be noted that $\mathrm{S} 2_{0}$ includes retained (RHC: $\mathrm{S} 1+\mathrm{S} 2$ ) and expelled hydrocarbons (EHC). Tables 5 and 6 show that RHC, which are in place unconventional hydrocarbons vary from 0.3 to 1.45 and from 0.3 to $4.78 \mathrm{mg} / \mathrm{g}$ rock and represent about $37 \%$ and $29 \%$ of $\mathrm{S} 2{ }_{0}$, respectively, in the Barremian and the Early Aptian series. Average $\mathrm{EHC}$ is twice greater than $\mathrm{RHC}$ and is, respectively, represented by 63 and $71 \%$ of $S 2_{0}$. This demonstrates release and migration of hydrocarbons outside the organicrich sedimentary facies then the relatively high maturity degree that is in oil window stage. The oil saturation index (OSI) is ranging from 5 to 137 (Tables 5 and 6) and is the witness of hydrocarbons migration (Fig. 6). Eventually, hydrocarbon generation potential (present day values) is still relatively higher in spite of relatively high maturity degree. Kerogen has not yet crushed its full potential for hydrocarbon production. The positive correlation between HGP and the TOC contents is an evidence of the source rock capacity to generate hydrocarbons in future and that's why it is considered such a good oil prone unconventional resource system.

Figures 6, 8, and 9 show two peaks that correlate positively with the two oceanic anoxic events: OAE1a and MBE. The positive correlation between $\mathrm{TOC}_{0}, \mathrm{~S} 2_{0}$, HGP, TR, RHC, EHC and TOC reveals the existence of two main source rocks with moderate to important uncounventional shale oil reserves. These source rocks are not homogenous and contain sedimentary intercalation of organic-rich and organic-poor facies. The first ones constitute the real source rock facies, and the second ones can be considered reservoir thin rocks. The little organic matter contained in the latter appears to result from the hydrocarbons migration produced and released by the organic-rich facies. The OSI that exceeds $100 \%$ is the proof (Jarvie 2012, 2015) (Tables 5 and 6).

\section{Shale oil resource system characterization}

The petroleum system elements consist of a mature source rock, migration pathway, reservoir rock and trap (Al-Hajeri et al. 2009). In the unconventional resource systems, all these components are associated in the same rock. The studied Barremian-Aptian series includes three types of facies: organic-rich black shales, organic-rich marls and organicpoor limestones and silicified black shales. The first two types constitute source rocks with the difference that black shales record the highest organic matter contents. They are good to very good hydrocarbon prone facies with an 
excellent organic matter quality which was very well preserved in the sedimentary environment. Organic-rich marls constitute a source rock of moderate quality. Its organic matter is lignocellulosic that may be carried with detrital particles. The organic-poor limestones can play the role of thin hydrocarbon reservoir and trap. Oil crossover constitutes an undeniable proof for that (Fig. 6). Since shale resource is made up of intercalated organic-rich and organic-poor sedimentary facies, when the mature stage occurs under high temperature and pressure, oil and gas saturation is attempt by thermal cracking kerogen which can trigger horizontal migration. As hydrocarbon generation and migration proceed with maturity progress, vertical migration take place and oil leaves organic_-rich facies (black shales) with high geochemical confinement degree to lodge in the poor-organic facies (limestones) that constitute close thin hydrocarbon reservoirs. This phenomenon was well demonstrated by geochemical and petrographical indicators for the Aptian-Albian shale resource system outcropping in the same region (Talbi et al. 2018). Those organic-poor facies may be attractive for unconventional oil explorers because they may help the hydrocarbons drainage by hydraulic fracturing operations due to the low degree of geochemical confinement (Jarvie 2012). Another element of the shale resource system is the open fractures that are frequent across the series and indeed, lead to hydrocarbon migration and drainage. Depending on the geologic and geochemical analysis and the degree of thermal maturity that is liquid oil window (Fig. 6), the two source rocks that had deposited during the two oceanic anoxic events OAE1a and MBE can be considered regarding Jarvie (2012) classification as "shale oil hybrid systems with a combination of juxtaposed organic-rich and organic-lean facies associated with open fractures".

\section{Factors controlling source rock deposition}

The Middel Cretaceous oceanic anoxic events had recorded majors black shales that provided most of the world's fossil fuels (Jenkyns 1980; Arthur et al. 1990; Ghasemi-Nejad 2009; Al-Ameri and Al-Obaydi 2011; Farzadi 2006; Sadooni and Alsharhan 2003; Genik 1993). Early Cretaceous anoxic events appear as preludes to them (Coccioni et al. 2003; Huck et al. 2013). The Current knowledge strongly suggests that the black shale deposits were associated with climatic variations leading to changes in surface water and deep water ecosystems (Leckie et al. 2002). This is the case of the MBE, whose hot humid climate ensured intense organic productivity and profound biotic changes (Malkoc and Mutterlose 2010; Ohkouchi et al. 2015) that could have probably primed the OAE1a (Bastide 2014; Huck et al. 2011). Marine productivity favored by increased nutrient supply and organic matter $(\mathrm{OM})$ preservation was the effect of anoxic/dysoxic conditions (Leckie et al. 2002). Those are the major processes used to explain the deposition of organicrich black shales. Depletion of oxygen in the substrate and even in the water column causes incomplete degradation of organic matter by anaerobic bacteria, leading to high TOC enrichment in the sediments (Leckie et al. 2002). In the Barremian-Aptian outcrop series of Jebel Oust, black shales generally exhibit good conservation of type I and type II organic matter. Therefore, Marls preserve less TOC contents than black shales. Its organic matter contain is made up of continental lignocellulosic origin which explains the higher OI values (OM type III). Then black shales are better source rocks than marls. Organic-poor facies are represented by limestones interbedded with marls and black shales and appear playing the role of thin hydrocarbon reservoirs. In fact, OSI is higher in limestone than in organic-rich black shales and marls. This variation in organic matter richness and quality in the different facies seems due to the regional and local geodynamic and paleogeographic evolution that impact the basin filling history (Liang et al. 2017; Talbi et al. 2018; Han et al. 2019). Two transgressive-regressive cycles bounded by two organic-rich black shales are deposited at Jebel Oust region that was an intracratonic basin formed by synjurassic rifting (Castany 1954; Chihi et al. 1984; Ben Ayed 1986) but whose collapse would certainly have been accelerated during the Early Cretaceous (Jauzein 1957; Ferjani et al. 2018). This basin was structured in horst and graben and tilted blocks, resulting from North to Northeast-trending regional extension (Fig. 3) developed along transforming EW faults (Ben Ayed 1986; Perthuisot et al. 1988; Naji et al. 2018). Since extensional rift tectonic origin was created instability of the bottom sea that prevents water stratification at the start of each sedimentary cycle., marl sediment production dominates the basin filling history at the beginning of the sedimentary cycle. The tectonic instability may induce low accumulation and preservation of $\mathrm{OM}$ in the basin that filled with organic and inorganic clastic debris from various sources. This is the case of marls which are associated with allochthonous OM with continental origin. The marls, which are filling depressions, show variations in thickness throughout the region. Above these marls, the black shales are generally deposited with a reduced and almost invariable thickness. The very fine regular laminations which characterize black shales deposits suppose a regular and extremely stable bottom (Talbi et al. 2018). The quantities of organic matter often well preserved in black shales assume the existence of stratified water bodies and a minimum oxygen bottom at the water-sediment interface. Then, black shales formation needs extreme tectonic stability, low-rate deposition and weak hydrodynamic interaction (Knapp et al. 2017) that favor their widespread deposition covering the major part of the tectonic deformation within the basin (Fig. 3). 
Each sedimentary cycle including the three stages (Fig. 3): basin structuring, basin marly filling and finally black shales deposition occurred during the transgression, at the maximum flooding surface (Vail et al. 1977; Jacquin and De Graciansky 1988; Frimmel et al. 2004). This is the case of OAE1a and MBE as shown in Fig. 8. Then, black shales will be covered by oxic deposits (oganicpoor limestones) before the initiation of the next sedimentary cycle. Indeed, the Early Late Barremian interval with poor-organic siliceous black shales and pure white nodular limestone overlie the organic-rich black shales of the MBE. The white nodular limestone shows gravity-driven deformation structures of the soft-sediment and abundant slumps at submarine slopes induced by North to Northeast-trending extension deformations (Naji et al. 2018). Those seafloor deformations accelerate the Late Barremian-Early Aptian sedimentary cycle in which OAE1a took place.

Hydrocarbons may be migrated using some of the preexisting reactivation normal faults. Retained hydrocarbons would be accumulated in subtle traps due to the presence of rock heterogeneities. This phenomenon was already well analyzed and demonstrated for organic-rich black shales of the Aptian-Albian series (Talbi et al. 2018). Then petroleum system related to the Barremian-Aptian interval of Jebel Oust series according to the Jarvie $(2012 ; 2015)$ classification is assimilated to "shale oil hybrid systems with a combination of juxtaposed organic-rich and organic-lean facies associated with open fractures".

\section{Conclusion}

The organic-rich black shales deposited in the Jebel Oust region are found within marine marly series containing rich microfauna with representative planktic benthic foraminefera assemblages. The first organic-rich black shale level, as recorded in the southern Tethyan margin, is dated Early Late Barremian and coincides with the occurrence of MBE which is widely represented in the northern Tethyan margin and seems to be the prelude of the second organic-rich black shale deposit that is dated Early Aptian and coincids with the OAE1a. Two transgressive-regressive cycles were deposited during the Early Cretaceous (Barremian-Aptian interval). They are mainly represented by marls with intercalations of limestones and black shales. Rock-Eval pyrolysis data distinguish black shales by means of high organic matter $(\mathrm{OM})$ contents, marls with moderately rich $\mathrm{OM}$ and silicified black shales and limestones as organic-poor facies. Average present day total organic carbon (TOC) contents are, respectively: $1.66,0.76$ and $0.35 \%$ wt. Type I and type II marine organic matter characterize only black shales with low hydrogen and oxygen index values (average $\mathrm{HI}=120$ and $\mathrm{OI}=66$ ) due to the relatively high maturity degree that corresponds to the end of the liquid oil window, whoever type III continental OM characterize marls with high OI and low $\mathrm{HI}$ values (average $\mathrm{HI}=117$ and $\mathrm{OI}=292$ ) and is interpreted as a contribution of an organic detrital sediments. Limestones recorded dispersed $\mathrm{HI}$ and OI values (average $\mathrm{HI}=117$ and $\mathrm{OI}=121$ ). Their $\mathrm{OM}$ is identified as hydrocarbons that would have migrated from source rocks (black shales) and trapped in the porosity of these organic-poor facies that constitute a thin reservoir rock intercalated with organic-rich facies. Then organic-rich black shales could be considered as dyoxic/anoxic facies and as oil prone source rock.

Since the sedimentary basin being of tectonic origin, geodynamic had controlled the organization of the fill basin system. The basin that was structured in horst and graben and tilted blocks, resulting from North to Northeast-trending regional extension, developed along transforming EW faults, got filled up early by marls that were deposited in the depressions formed after each distensive tectonic activity. Parallel to the gradual change in the mean sea level, the unevenness of the seafloor inequality gradually fades and the organicrich black shales settle coinciding with the maximum flooding events of marine transgressions and the start. MBE black shales recorded $1.5 \% \mathrm{wt}$ for average $\mathrm{TOC}_{0}$ and nearby $7 \mathrm{mg}$ $\mathrm{HC} / \mathrm{g}$ for $\mathrm{S} 2_{0}$.

The higher values of estimated $\mathrm{TOC}_{0}(4 \% \mathrm{wt})$ and $\mathrm{S} 2_{0}$ (19.36 mg HC/g) characterize OAE1a black shales. This suggests that OAE1a represents an increase in marine organic productivity and / or environmental proxies indicating anoxiadysoxia that may be initiated at MBE.

Present day OM contents recorded in OAE1a black shales are higher than in those of MBE. TR is more important for MBE black shales (82\%) than for OAE1a ones (67\%) due to the high maturity degree for the Barremian sediments. In consequence, the major part of the initial hydrocarbons is crashed and expelled from the two source rocks. Average RHC is nearby $20 \%$. However average EHC is about $80 \%$. OSI is with high dispersed values (9-137) which indicate hydrocarbon released and expelled from source rocks. As long as those source rocks present significant quantities of hydrocarbons in place that can circulate since the degree of thermal maturity corresponds to the oil window, these two source rocks are considered to be an unconventional shale oil system. Taking into account the tectonic structure, the geochemical parameters and the various sedimentary facies, the shale resource system is mainly represented by black shales formed during the two anoxic oceanic events MBE and OAEla which are oil prone source rocks categorized as "shale oil hybrid system with a combination of juxtaposed organic-rich and organiclean facies associated with open fractures".

Acknowledgements This work was conducted with the support of the Ministry of Higher Education and Scientific Research of Tunisia. The 
authors thank the Springer Journal's Editorial staff, in particular Dr Turgay Ertekin, for their insightful comments and judicious recommendations. We are especially grateful to anonymous reviewers for their hard work, constructive remarks and comments which helped to greatly improve the quality of the manuscript.

Funding The authors do not received any specific funding for this work.

\section{Declarations}

Conflict of interest The authors declare that they have no conflicts of interest.

Open Access This article is licensed under a Creative Commons Attribution 4.0 International License, which permits use, sharing, adaptation, distribution and reproduction in any medium or format, as long as you give appropriate credit to the original author(s) and the source, provide a link to the Creative Commons licence, and indicate if changes were made. The images or other third party material in this article are included in the article's Creative Commons licence, unless indicated otherwise in a credit line to the material. If material is not included in the article's Creative Commons licence and your intended use is not permitted by statutory regulation or exceeds the permitted use, you will need to obtain permission directly from the copyright holder. To view a copy of this licence, visit http://creativecommons.org/licenses/by/4.0/.

\section{References}

Al-Ameri TK, Al-Obaydi RY (2011) Cretaceous petroleum system of the khasib and tannuma oil reservoir, East Baghdad oil field. Iraq Arab J Geosci 4(5-6):915-932

Al-Hajeri MM, Al Saeed M, Derks J, Fuchs T, Hantschel T, Kauerauf A et al (2009) Basin and petroleum system modeling. Oilfield Rev 21(2):14-29

Arthur MA, Brumsack HJ, Jenkyns HC, Schlanger SO (1990) Stratigraphy, geochemistry, and paleoceanography of organic carbon-rich Cretaceous sequences. Cretac Res Events Rhythms. https://doi. org/10.1007/978-94-015-6861-6_6

Bastide F (2014) Synthèse de l'évolution de la plateforme urgonienne (Barrémien tardif à aptien précoce) du Sud-Est de la France: Faciès, micropaléontologie, géochimie, géométries, paléotectonique et géomodélisation. Doctoral dissertation, Université de Lausanne, Faculté des géosciences et de l'environnement

Bellier JP, Moullade M (2002) Lower cretaceous planktonic foraminiferal biostratigraphy of the western north atlantic (ODP Leg 171B), and taxonomic clarification of key index species. Rev Micropaléontol 45(1):9-26. https://doi.org/10.1016/S0035-1598(02) 80003-4

Ben Ayed N (1986) Evolution tectonique de l'Avant-pays de la chaine alpine de Tunisie du Mésozoïques a 'l'Actuel. Dissertation, Université Paris Sud Orsay

Bodin S, Fiet N, Godet A, Matera V, Westermann S, Clément A et al (2009) Early cretaceous (late berriasian to early aptian) palaeoceanographic change along the northwestern tethyan margin (vocontian trough, southeastern France): $\delta 13 \mathrm{C}, \delta 18 \mathrm{O}$ and $\mathrm{Sr}$-isotope belemnite and whole-rock records. Cretac Res 30(5):1247-1262

Bralower TJ, Arthur MA, Leckie RM, Sliter WV, Allard DJ, Schlanger SO (1994) Timing and paleoceanography of oceanic dysoxia/ anoxia in the late barremian to early aptian (Early Cretaceous). Palaios. https://doi.org/10.2307/3515055
Burollet PF (1991) Structures and tectonics of Tunisia. Tectonophysics 195(2-4):359-369. https://doi.org/10.1016/0040-1951(91) 90221-D

Calvert SE, Bustin RM, Pedersen TF (1992) Lack of evidence for enhanced preservation of sedimentary organic matter in the oxygen minimum of the Gulf of California. Geology 20(8):757-760. https://doi.org/10.1130/0091-7613(1992)020\%3c0757:LOEFEP\% 3e2.3.CO;2

Castany G (1954) Les grands traits structuraux de la Tunisie. Bulletin de la Société géologique de France 6(1-3):151-173. https://doi. org/10.2113/gssgfbull.S6-IV.1-3.151

Chida-Ben Haj Ali N 2005. Les foraminifères planctoniques du Crétacé (Hauterivien à Turonien inférieur) de Tunisie : systématique, biozonation et précisions stratigraphiques. Dissertation, University of Tunis II

Chihi L, Dlala M, Ayed NB (1984) Manifestations tectoniques synsedimentaires et polyphasées d'âge crétacé moyen dans l'atlas tunisien central (région de kasserine). Comptes-rendus des seances de l'acade'mie des sciences. Serie 2 mecanique-physique chimie sciences de lunivers sciences de la terre 298(4):141-146

Coccioni R, Erba E, Premoli-Silva I (1992) Barremian-Aptian calcareous plankton biostratigraphy from the Gorgo Cerbara section (Marche, central Italy) and implications for plankton evolution. Cretac Res 13(5-6):517-537. https://doi.org/10.1016/01956671(92)90015-I

Coccioni R, Galeotti S, Sprovieri M (2003) The Mid-Barremian Event (MBE): the prelude to the OAE1a. AGU.

Coccioni R, Luciani V, Marsili A (2006) Cretaceous oceanic anoxic events and radially elongated chambered planktonic foraminifera: paleoecological and paleoceanographic implications. Palaeogeogr Palaeoclimatol Palaeoecol 235(1-3):66-92. https://doi.org/ 10.1016/j.palaeo.2005.09.024

Demaison GJ, Moore GT (1980) Anoxic environments and oil source bed genesis. AAPG Bull 64(8):1179-1209

Elkhazri A, Abdallah H, Razgallah S, Moullade M, Kuhnt W (2013) Carbon-isotope and microfaunal stratigraphy bounding the Lower Aptian Oceanic Anoxic Event 1a in northeastern Tunisia. Cretac Res 39:133-148. https://doi.org/10.1016/j.cretres.2012.05.011

Espitalie J, Madec M, Tissot B, Mennig JJ, Leplat P (1977) Source rock characterization method for petroleum exploration. Offshore Technol Conf. https://doi.org/10.4043/2935-MS

Farzadi P (2006) The development of middle cretaceous carbonate platforms, Persian Gulf, Iran: constraints from seismic stratigraphy, well and biostratigraphy. Pet Geosci 12(1):59-68

Ferjani AH, Guellala R, Amiri A, Merzougui A, Inoubli MH (2018) Structuration profonde dans la région de Bir M'Chergua (NordEst de la Tunisie). Implic Hydrogéol Estudios Geol 74(1):075. https://doi.org/10.3989/egeol

Fournie D, Pacaud M (1973) Esquisses sédimentologiques et paléogéographiques sur le Crétacé inférieur de Tunisie, du Berriasien au Barrémien. Livre Jubilaire M. Solignac Ann Mines et Géol Tunis, vol 26, pp 149-168

Frimmel A, Oschmann W, Schwark L (2004) Chemostratigraphy of the posidonia black shale, SW Germany influence of sea-level variation on organic facies evolution. Chem Geo 206(3-4):199-230

Gharbi M, Espurt N, Masrouhi A, Bellier O, Amari EA (2015) Style of atlassic tectonic deformation and geodynamic evolution of the southern Tethyan margin, Tunisia. Mar Pet Geol 66:801-816. https://doi.org/10.1016/j.marpetgeo.2015.07.020

Ghasemi-Nejad E, Head MJ, Naderi M (2009) Palynology and petroleum potential of the Kazhdumi Formation (Cretaceous: AlbianCenomanian) in the South Pars field, northern Persian Gulf. Mar Pet Geol 26(6):805-816. https://doi.org/10.1016/j.marpetgeo. 2008.05.005

Genik GJ (1993) Petroleum geology of cretaceous-tertiary rift basins in Niger, Chad, and Central African Republic. AAPG Bull

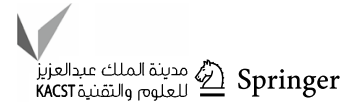


77(8):1405-1434. https://doi.org/10.1306/BDFF8EAC-171811D7-8645000102C1865D

Godet A, Hfaiedh R, Arnaud-Vanneau A, Zghal I, Arnaud H, Ouali J (2014) Aptian palaeoclimates and identification of an OAE1a equivalent in shallow marine environments of the southern Tethyan margin: evidence from Southern Tunisia (Bir Oum Ali section, Northern Chott Chain). Cretac Res 48:110-129. https://doi. org/10.1016/j.cretres.2013.12.006

Graziano R (2013) Sedimentology, biostratigraphy and event stratigraphy of the Early Aptian oceanic anoxic event (OAE1A) in the Apulia Carbonate Platform margin-Ionian basin system (Gargano promontory, southern Italy. Cretac Res 39:78-111. https://doi.org/ 10.1016/j.cretres.2012.05.014

Guiraud R, Maurin JC (1991) Le Rifting en Afrique au Cretace inferieur; synthese structurale, mise en evidence de deux etapes dans la genese des bassins, relations avec les ouvertures oceaniques periafricaines. Bulletin de la Soci géol de France 162(5):811-823. https://doi.org/10.2113/gssgfbull.162.5.811

Han Y, Horsfield B, Mahlstedt N, Wirth R, Curry DJ, LaReau H (2019) Factors controlling source and reservoir characteristics in the Niobrara shale oil system, Denver Basin. AAPG Bull 103(9):20452072. https://doi.org/10.1306/0121191619717287

Huck S, Heimhofer U, Rameil N, Bodin S, Immenhauser A (2011) Strontium and carbon-isotope chronostratigraphy of BarremianAptian shoal-water carbonates: Northern Tethyan platform drowning predates OAE 1a. Earth Planet Sci Lett 304(3-4):547-558. https://doi.org/10.1016/j.eps1.2011.02.031

Huck S, Heimhofer U, Immenhauser A, Weissert H (2013) Carbonisotope stratigraphy of Early Cretaceous (Urgonian) shoal-water deposits: diachronous changes in carbonate-platform production in the north-western Tethys. Sed Geol 290:157-174. https://doi. org/10.1016/j.sedgeo.2013.03.016

Jacquin T, De Graciansky PC (1988) Cyclic fluctuations of anoxia during Cretaceous time in the South Atlantic Ocean. Mar Pet Geol 5(4):359-369

Jarvie DM (2012) Shale resource systems for oil and gas part 2-shaleoil resource systems. In: Breyer JA (ed) shale reservoirs giant resources for the 21st century. AAPG, Costa Rica

Jarvie DM (2015) Geochemical assessment of unconventional shale gas resource systems. Fund Gas Shale Res. https://doi.org/10.1002/ 9781119039228.ch3

Jarvie DM, Hill RJ, Ruble TE, Pollastro RM (2007) Unconventional shale-gas systems: the Mississippian Barnett Shale of north-central Texas as one model for thermogenic shale-gas assessment. AAPG Bull 91(4):475-499. https://doi.org/10.1306/12190606068

Jauzein A (1957) Notice explicative de la carte géologique de Bir M'Cherga à l'échelle 1: 50000. Service Géologique de Tunisie.

Jenkyns HC (1980) Cretaceous anoxic events: from continents to oceans. J Geol Soc 137(2):171-188. https://doi.org/10.1144/ gsjgs.137.2.0171

Knapp GL, Mukherjee T, Zuback JS, Wei HL, PalmerDe TAA, DebRoy TJ (2017) Building blocks for a digital twin of additive manufacturing. Acta Mater 135:390-399. https://doi.org/10.1016/j.actam at.2017.06.039

Leckie RM, Bralower TJ, Cashman R (2002) Oceanic anoxic events and plankton evolution: biotic response to tectonic forcing during the mid-Cretaceous. Paleoceanography 17(3):13-21. https://doi. org/10.1029/2001PA000623

Liang C, Cao Y, Jiang Z, Wu J, Guoqi S, Wang Y (2017) Shale oil potential of lacustrine black shale in the Eocene Dongying depression: implications for geochemistry and reservoir characteristics. AAPG Bull 101(11):1835-1858. https://doi.org/10.1306/01251 715249

Luciani V, Cobianchi M, Lupi C (2006) Regional record of a global oceanic anoxic event: OAE1a on the Apulia Platform margin,
Gargano Promontory, southern Italy. Cretac Res 27(6):754-772. https://doi.org/10.1016/j.cretres.2006.01.003

Malkoc M, Mutterlose J (2010) The early Barremian warm pulse and the late Barremian cooling: a high-resolution geochemical record of the Boreal Realm. Palaios 25(1):14-23. https://doi.org/10.2110/ palo.2010.p09-029r

Marie J, Trouvé P, Desforges G, Dufaure PH (1982) Nouveaux éléments de paléogéographie du Crétacé de Tunisie. Cretac Res 3(1-2):167-170. https://doi.org/10.1016/0195-6671(82)90017-9

Memmi L (1989) Le Crétacé inférieur (Berriasien-Aptien) de Tunisie: biostratigraphie, paléogéographie et paléoenvironnements. Dissertation, Université Claude-Bernard

Moosavizadeh MA, Mahboubi A, Moussavi-Harami R, Kavoosi MA (2014) Early Aptian oceanic anoxic event (OAE 1a) in Northeastern Arabian Plate setting: an example from Dariyan Formation in Zagros fold-trust belt. SE Iran Arab J Geosci 7(11):4745-4756. https://doi.org/10.1007/s12517-013-1025-Z

M'rabet A, (1981) Différenciation des environnements de formation de dolomite, Crétacé inférieur du centre de la Tunisie. Sédimentologie 28(3):331-352

Naji C, Gharbi M, Zayneb A, Masrouhi A, Bellier O (2018) Temporal and spatial changes of the submarine Cretaceous paleoslope in Northern Tunisia, inferred from slump folds analysis. Proc Geol Assoc 129(1):40-56. https://doi.org/10.1016/j.pgeola.2017.10.006

Ohkouchi N, Ogawa NO, Chikaraishi Y, Tanaka H, Wada E (2015) Biochemical and physiological bases for the use of carbon and nitrogen isotopes in environmental and ecological studies. Prog Earth Planet Sci 2(1):1-17

Perthuisot V, Rouvier H, Smati A (1988) Style et importance des deformations antevraconiennes dans le Maghreb oriental; exemple du diapir du Jebel Slata (Tunisie centrale). Bulletin de la Soci Géol de France 4(3):391-398. https://doi.org/10.2113/gssgfbull.IV.3.391

Petersen HI, Rosenberg P, Nytoft HP (2008) Oxygen groups in coals and alginite-rich kerogen revisited. Int J Coal Geol 74(2):93-113. https://doi.org/10.1016/j.coal.2007.11.007

Sadooni FN, Alsharhan AS (2003) Stratigraphy, microfacies, and petroleum potential of the Mauddud Formation (Albian-Cenomanian) in the Arabian Gulf basin. AAPG Bull 87(10):1653-1680. https:// doi.org/10.1306/04220301111

Saïd A, Baby P, Chardon D, Ouali J (2011) Structure, paleogeographic inheritance and deformation history of the southern Atlas foreland fold and thrust belt of Tunisia. Tectonics. https://doi.org/10.1029/ 2011TC002862

Salaj J (1978) The geology of the Pelagian block the eastern Tunisian platform. In: Nairn AEM, Kanes WH, Stehli FG (eds) The Ocean Basins and Margins. Springer, Boston

Salaj J. (1980).Microbiostratigraphie du Crétacé et du Paléogène de la Tunisie Septentrionale et Orientale. Geologický ústav Dionýza Štúra

Smati A (1986) Les gisements de Pb-Ba et de Fe du Jebel Slata (Tunisie du Centre-Nord): minéralisations épigénétiques dans le crétacé nérétique de la bordute d'un diapir de trias: gisements de Sidi Amor Ben Salem et de Slata-Fer. Dissertation, Paris

Soua M (2016) Cretaceous oceanic anoxic events (OAEs) recorded in the northern margin of Africa as possible oil and gas shale potential in Tunisia: an overview. Int Geol Rev 58(3):277-320. https:// doi.org/10.1080/00206814.2015.1065516

Sprovieri M, Coccioni R, Lirer F, Pelosi N, Lozar F (2006) Orbital tuning of a lower cretaceous composite record Maiolica Formation, central Italy. Paleoceanography. https://doi.org/10.1029/2005P A001224

Sykes R, Snowdon LR (2002) Guidelines for assessing the petroleum potential of coaly source rocks using rock-eval pyrolysis. Org Geochem 33(12):1441-1455. https://doi.org/10.1016/S01466380(02)00183-3 
Talbi R (1991) Etude géologique et géochimique des faciès riches en matière organique d'âge albien du bassin de Bir M'Cherga (NE de Tunisie): Déterminisme de leur genèse et intérêt pétrolier de la région. Dissertation, University of Tunis II

Talbi R, Lakhdar R, Smati A, Spiller R, Levey R (2018) Aptian-Albian shale oil unconventional system as registration of Cretaceous oceanic anoxic sub-events in the southern Tethys (Bir M'Cherga basin, Tunisia). J Pet Explor Prod Technol 9(2):1007-1022. https://doi.org/10.1007/s13202-018-0577-6

Vail PR, Mitchum jrRM, Thompson III S (1977) Seismic stratigraphy and global changes of sea level part relative changes of sea level from coastal onlap section 2 application of seismic reflection. Configuration to Stratigrapic Interpretation, 63-81
Wulff L, Mutterlose J, Bornemann A (2020) Size variations and abundance patterns of calcareous nannofossils in mid Barremian black shales of the Boreal Realm (Lower Saxony Basin). Mar Micropaleontol. https://doi.org/10.1016/j.marmicro.2020.101853

Yilmaz IO, Altiner D, Tekin UK, Ocakoglu F (2012) The first record of the "Mid-Barremian" Oceanic Anoxic Event and the Late Hauterivian platform drowning of the Bilecik platform, Sakarya Zone, western Turkey. Cretac Res 38:16-39. https://doi.org/10. 1016/j.cretres.2012.04.010

Publisher's Note Springer Nature remains neutral with regard to jurisdictional claims in published maps and institutional affiliations. 